Elsevier Science Publishers B.V., Amsterdam - Printed in the Netherlands

\title{
SYMBOLISM AND SURVIVAL IN DEVELOPING ORGANIZATIONS: REGIONAL COLLEGES IN ISRAEL [1]
}

\author{
ZELDA F. GAMSON \\ University of Michigan, U.S.A. \\ TAMAR HOROWITZ \\ Henriette Szold National Institute for Research in the Behavioral Sciences, Jerusalem
}

\begin{abstract}
This article draws on the work of John Meyer and others who look at the institutional side of organizations. We analyze the origins and early history of a system of regional colleges in Israel in the context of an emerging postsecondary system. We argue that the terms used to define legitimacy, as well as who defines it, are crucial issues in the institutionalization of educational organizations, especially colleges and universities.
\end{abstract}

Thinking about the relations between organizations and environments has advanced considerably in the last decade. Within a year of one another, three important books in this area have appeared - Organizations and Environments by Howard Aldrich (1979), Environments and Organizations by Marshall W. Meyer and Associates (1978), and The External Control of Organizations by Jeffrey Pfeffer and Gerald R. Salancik, (1978). Whether they take the perspective of resource-dependence (Aldrich and Pfeffer, 1976; Pfeffer and Salancik, 1978), ecology (Aldrich, 1979; Aldrich and Pfeffer, 1976) or institutionalized nonrationality (Meyer and Associates, 1978), all of these works have in common the attempt to provide a more differentiated picture of "the environment" and a clearer specification of the effects of particular environmental characteristics on organizations than has been available until now. All emphasize the necessity of looking at these relationships longitudinally in a variety of institutional sectors, ideally across different historical periods in several societies.

We will not review this work here; for a good start, the books cited above 
present original research on the organization-environment nexus or recast findings from other research in these terms. Research on organizations based on exchange theory (Blau, 1964; Jacobs, 1974; Levine and White, 1961; Salancik and Pfeffer, 1974; Talbert, 1979) and on concepts derived from political economy (Aldrich and Pfeffer, 1976; Benson, 1975; Yuchtman and Seashore, 1967; Zald, 1970) are frequently impelled to examine relationships among organizations to understand what happens within organizations.

Attempts to account for apparent nonrationalities in many modern organizations, especially highly institutionalized ones like schools and social service agencies, have looked increasingly at the connections between those organizations and other parts of the society to explain their origins, vicissitudes and survival (Bowles and Gintis, 1976; Collins, 1979; Larson, 1977; Levin, 1980; Meyer and Brown, 1978; Wiley and Zald, 1968). This article grows out of the latter corpus of work. Drawing on the work of John Meyer (Meyer, 1970; Meyer and Rowan, 1977), we look at the origins and early history of a system of regional colleges in Israel in terms of their institutionalization as legitimate members of a network of educational organizations. We argue that the terms used to define legitimacy and who defines it are crucial issues in the institutionalization of educational organizations, particularly colleges and universities.

\section{Institutionalized Organizations}

Building on the insights of Weick (1976) and Cohen and March (1974) into the nonrationality and apparent inefficiency of organizations that are neither driven by markets nor produce clearly measurable outputs, John Meyer tries to clarify how such organizations can survive and even thrive. They engage in activities, such as the instruction of the young, the incarceration of criminals, the certification of professionals, or the treatment of the mentally and physically ill that touch on societal commitments that go beyond the particular operations of particular organizations. General conceptions and justifications are likely to be applied to and invoked by organizations of these sorts both to attract and maintain support. Over time, these conceptions and justifications come to be taken for granted; they become myths that "take on a rulelike status in thought and action" (Meyer and Rowan, 1977, p. 341). Institutionalization is the process whereby those myths come to define obligations and actions in particular circumstances. In modern societies, the prevailing myths for organizations provide definitions of rationality. Institutionalized rules define what organizational work - the production of certain products and services, the techniques whereby they are produced, the policies and programs which govern them - will be considered rational.

Institutionalized rules are to be sharply distinguished from actual behavior. 
Indeed, they often conflict with efficiency criteria; this leads to loose coupling between the institutionalized realm and actual day-to-day activities. In general, Meyer and Rowan (1977) argue that organizations are likely to incorporate indeed welcome - the practices and procedures of the institutional sector most relevant to them in order to enhance their legitimacy and to improve their prospects for survival. As a result, over time the formal structure of many organizations reflects their institutional environments more than the exigencies of markets, clients, and resources. As organizations' relations with their environments become more complex, bureaucratic structures and rules are likely to develop. These give the kind of legitimated rationality thought to be appropriate for controlling and standardizing organizational activities. There then appears an increasing isomorphism between organizations and their environments, as they come to reflect socially constructed definitions of rational practices.

The adoption of institutionally-defined elements "provides an account of its activities that protects the organization from having its conduct questioned. The organization becomes, in a word, legitimate, and it uses its legitimacy to strengthen its support and secure its survival.... [This enables] an organization to remain successful by social definition, buffering it from failure" (Meyer and Rowan, 1977, p. 349). The aspects of organizations that most reflect institutional effects are (1) assessment criteria, which increasingly are defined in terms convincing to important groups in the environment, and (2) the link between performance and the acquisition of resources, which becomes increasingly loose as resources are provided on the basis of legitimacy rather than efficiency.

These forces do not necessarily proceed smoothly. Quite typically there are conflicts between the day-to-day activities of the organization and its efforts to conform to rules set by the institutionalized realm. There may be conflicts of another kind among those parts of the environment that hold up different rules of rationality. In response to such inconsistencies, institutionalized organizations are likely to incorporate all sorts of incompatible and conflicting elements. In such a situation, loose coupling among the elements is almost guaranteed.

The analysis of the case of regional colleges will extend Meyer and Rowan's (1977) framework to issues they raise but do not pursue, in particular the antecedents and processes whereby institutionalization proceeds. We will see in the Israeli case that institutionalization may involve a good deal of inconsistency and even conflict between organizations and their environments, as well as among different parts of the environment. This case suggests that inconsistencies and conflicts, as they unfold over time, may not necessarily be resolved, with important consequences not only for a particular organization but for the institutional sector as well.

In the case of the regional colleges in Israel, there was considerable inconsistency among the various groups that provided resources to the colleges. Organizations which operate in institutionalized sectors in which there is conflict 


\section{4}

among resource givers will find such conflict more problematic than marketdriven organizations (Hall et al., 1977). Institutionalized organizations which experience little conflict among resource givers will, paradoxically, have more freedom than those which must confront much conflict. This is because, following Meyer and Rowan's (1977) argument, the basis for the survival of institutionalized organizations lies precisely in the development of myths about their rightness and structures that exemplify those myths. When important outsiders disagree, it is difficult for organizations in institutionalized sectors to enunciate a myth and structure acceptable to all.

This is particularly true when the conflict among resource givers centers on the identity and definition of the organization. This means that one of the key issues in the institutionalization of an organization - legitimacy - is constantly being questioned (Dowling and Pfeffer, 1975). Organizational boundaries will be fuzzy, activities and formal structures considered to be appropriate will shift, and even what the organization is to be called will be problematic (Meyer and Rowan, 1977). As we will see, conflicts among resource givers will have a much more powerful impact on the institutional side of the organization - the symbols it uses to identify itself, the policies it enunciates, and the justifications it gives for its activities - than on day-to-day behavior.

\section{General Characteristics of the Israeli Case}

We will turn in a moment to the specific case of regional colleges in Israel but first let us state some of its general characteristics. Table I summarizes the general features of the Israeli case according to the characteristics of the focal organization, the resource system, and the relevant institutional context. By "focal organization" we mean the organization or organizations that are the recipients of resources and the targets of the attention of the institutional context. Characteristics of focal organizations include their number, their age, the dispersion among them, their policy-making bodies, the familiarity of their operations, and the extent to which their outputs are measurable and their operations market-driven. By "resource system" we include the certainty of resources for the focal organization, the number of resource givers, the dispersion among them, and dominance relations among them (Benson, 1975). By "relevant institutional context" we mean the organizations that impinge most on the focal organization; these include resource givers as well as other organizations. Within the relevant institutional environment, we include the number of organizations, the degree to which they are institutionalized within the larger society, the formality of relationships among them, dominance relations among them, and the consistency among their views of the focal organization.

The case we are dealing with involves relatively new, dispersed and unin- 
TABLE I

General Characteristics of the Regional College Case

Characteristics of the Focal Organization

- Relatively new

- Several focal organizations

- Focal organizations dispersed

- Focal organizations uninfluential on external policy-making bodies

- Engaged in operations seen as unfamiliar in the larger society

- Outputs not easily measured

- Operations not market-driven

- Operations of various kinds brought together within the same organizational boundary

Resource System

- Resources relatively certain

- Two major resource givers, several minor resource givers

- Resource givers dispersed

- No clearly dominant resource givers

Relevant Institutional Context

- Five major organizations, several minor ones

- Each organization highly institutionalized within the larger society

- Relationships among these organizations relatively new and unformalized

- No clearly dominant organizations

- Inconsistencies and conflicts among major organizations" view of the focal organizations

fluential focal organizations engaged in operations that are not market-driven, whose outputs are not easily measured. Furthermore, what they do is unfamiliar. The resources available to the focal organizations are relatively certain. There are several resource givers who are dispersed and no single one is dominant. The focal organizations are faced with an institutional context composed of several different major organizations, each highly institutionalized within the larger society. As a set, however, the relationships among these organizations are relatively new and informal, with none clearly dominant. Most important of all, their views of the focal organizations are inconsistent.

\section{Institutional Context: The Israeli Educational System [2]}

Postsecondary education in Israel is divided into two sectors that differ sharply from each other in origins, age, financing, autonomy, and culture. While there are differences in the age, innovativeness and accessibility of the seven universities comprising the university sector - Hebrew University, Tel Aviv, 
Bar-Ilan, the Technion, Haifa, Ben-Gurion, and the Weizmann Institute - they are older, more traditional, more autonomous, and more meritocratic than the nonuniversity sector. The latter, consisting of a potpourri of over 150 specialized programs scattered throughout the nation, are relatively new, innovative, dependent on local needs, and egalitarian. Their enrollments are half that of the seven universities $(27,287$ students altogether in 1977-1978 compared to 54,060 in all the universities) [3].

Entrance to universities requires a certificate earned by passing a special matriculation examination; this requirement does not apply to most nonuniversity institutions. Most secondary students who acquire the matriculation certificate continue their studies, the large majority at universities. But not all students who attend secondary schools finish, nor do all those who finish get the matriculation certificate. In 1977, for example, about $40 \%$ of the twelfth grade students sat for the matriculation examination; of these, the percentage of students of Asian-African origins was much lower than those of European origins. This fact has led to a much smaller representation of "Oriental" Jews in the universities. Nonuniversity institutions, which do not require a matriculation certificate, enroll more Asian-African students (Israel Bureau of Statistics, 1979).

All of the universities receive the largest proportion of their budgets from the state. Until 1974, each university negotiated its allocation with the central treasury. Now, university budgets are determined by a Central Planning and Grants Committee established in 1974. In contrast, not all nonuniversity institutions are state-supported; those that are receive their funds from the Ministry of Education.

The certification of universities and nonuniversity institutions is also different. The Council for Higher Education, a quasi-governmental body dominated by academics from the universities, reviews the universities and other institutions offering the B.A. It has performed this role in a lighthanded way and only recently has it taken on some of the trappings of a central body for higher education. Nonuniversity institutions have been regulated even less. Hundreds of postsecondary programs were founded in the last fifteen years by religious institutions, the labor movement, political parties, and ad hoc interest groups. These programs are not required to meet any certification requirements unless they apply for state funds. In such a case, the Ministry of Education is responsible for reviewing them. The openness - almost anarchy - of Israeli postsecondary education has profoundly affected the institutionalization of the newest entrants to the field, the regional colleges.

\section{Focal Organization: Origins of the Regional Colleges}

Table II presents a chronology of the most important events and decisions 
TABLE II

Chronology of Major Events and Decisions Affecting Regional Colleges

1958 - Law establishing the Council for Higher Education

1960s - Regional colleges established

- Ministry of Education begins to enunciate policies to increase equality of educational opportunity

- Higher education expands

Late-1960s - Kibbutz movement loses interest in regional colleges

1971 - Lifson Committee issues a blueprint for the development of postsecondary education favorable to the regional colleges

- Heads of regional colleges circulate document suggesting that they award academic degrees

$1972-1958$ law establishing the Council for Higher Education is amended empowering the Council with licensing authority for institutions of postsecondary education

- Central Committee established to look into postsecondary scene

- Porat Committee established and soon disbanded

$1973-$ Central Committee disbanded

1974 - Law establishing the Planning and Grants Committee

1975 - Council for Higher Education summarizes its internal discussions of the regional colleges introducing the distinction between "authorized" colleges and unauthorized colleges

Mid-1970s - Enrollments and funding for higher education level off

1977 - Poliakov Committee recommends that regional colleges take necessary steps to become authorized colleges; recommendation never implemented

- 1958 law establishing the Council for Higher Education is amended asserting that "college" is no longer a protected term carrying approved academic status

1978 - Appointment of a special staff member in the Ministry of Education to deal with regional colleges

- Meyer Committee recommends that extension arrangements between the regional colleges and universities be made more systematic

1979 - Meyer Committee made a permanent committee of the Council for Higher Education, with academic and nonacademic subcommittees 
that have affected the development of the regional colleges. The pages to follow flesh out the chronology.

The regional college as a form appeared on the Israeli scene for the first time in the mid-1960s, just as postsecondary education as a whole was expanding in the nation. Housed originally in regional kibbutz schools, the regional colleges emerged from adult education centers the kibbutzim established mainly to provide short courses in art and cultural subjects for their members [4]. Soon after, such courses were supplemented by others in technical subjects and, a little later, by courses taught by faculty from the universities which carried credit toward the BA. At this point, the various courses were not sharply distinguished from one another [5].

Why were the kibbutzim interested in starting the regional colleges? For years, the assumption among kibbutz members was that studying for itself was more important than gaining credentials and degrees (Gamson and Palgi, 1982). During the $1960 \mathrm{~s}$, this stance proved to be unstable as an increasing number of the second generation became critical of their isolation from the larger society. One of the reasons they often gave for wanting to move in a wider world was their desire for higher education (Rosner, 1982). After much debate, the kibbutzim began making arrangements with existing universities, the Ministry of Education and other educational agencies to provide greater access to postsecondary education for their members. The regional colleges represent one early effort in this direction [6].

The climate for the establishment of regional colleges was especially favorable in Israel during the 1960s. In this period, the Ministry of Education was beginning to recognize that equalizing educational opportunity, especially for those of Asian-African origins, required more than providing the same educational resources for different groups in the population. Equal education also meant the provision of compensatory and enrichment programs so that students could take advantage of the new opportunities open to them (Horowitz, 1980; Smilansky, 1973). This principle applied to postsecondary education, since there were many secondary school graduates without the matriculation certificate who could, therefore, not enter the universities. Here, kibbutz members and people from disadvantaged backgrounds shared an interest in broadening access to postsecondary education. In this, they received support from the highest officials in the Ministry of Education.

Local authorities also provided enthusiastic support for the regional colleges. In Israel, as in most developing countries, there is a problem of migration from the periphery to the cities. The central government tries to prevent this trend in a variety of ways through the provision of better housing, local employment opportunities, and educational services. Local authorities were particularly interested in offering educational programs which might attract and hold the populations in their regions. 
The university system, in the meantime, was in the process of expansion during the 1960s. Between 1960 and 1972, enrollments in postsecondary education overall increased at annual rates of between $10 \%$ and $18 \%$. Four of the seven universities which exist today did not become full-fledged universities until 1969 . Around this period, there was an attempt to establish a university for the large labor movement, the Histadrut. Many other attempts were made to open postsecondary institutions in this period in the hope that they would be able to give regular academic degrees in the future. People in the Ministry of Education were also paying attention to developments in the United States that might provide alternatives in Israel, such as community colleges, adult programs and the like.

\section{A Change in Kibbutz Support for the Regional Colleges: The Struggle Begins}

When the first regional college opened in the mid-1960s, its leadership and management came almost exclusively from the kibbutzim. Four colleges were founded in a short period of time and three later. When they were first estblished, the colleges did not have an agreed-upon name. As each began to offer a range of courses, it began to be called "michlala," a general term in Hebrew for "college". No official body at that time was empowered to decide who could appropriate the term "michlala," nor was there a system in Israel for chartering and certifying such institutions. As Meyer and Rowan (1977) emphasize, struggles over names are critical in the institutionalization of organizations. As we shall see, what to call the regional institutions has been a continuing struggle throughout their history.

Almost from the beginning, life was complicated for the colleges. While the kibbutzim, regional authorities and the Ministry of Education had a common interest in seeing the regional colleges provide postsecondary opportunities to local populations, who would be served and how they should be served needed to be worked out. Egalitarian ideals, however impressive in the abstract, can be implemented in a variety of ways.

At the beginning, the heads of the regional colleges tilted more toward their kibbutz students than toward the students from nearby agricultural villages and towns. But just as the Ministry of Education and the regional authorities began to accept the regional colleges as institutions which would help realize their social policies, the kibbutzim began to lose interest in them. The colleges were no longer seen as attractive to young kibbutz members, who found it difficult to attend the colleges after a day's work, did not find the intellectual atmosphere challenging enough, and saw them as considerably less prestigious than the universities, which they began attending in larger numbers (Gamson and Palgi, 1982). 
With the withdrawal of full support from the kibbutz movement, the kibbutz members who staffed the regional colleges found themselves without an independent political base or a clear source of legitimacy. On one hand, they shared with regional authorities and the Ministry of Education an egalitarian ideal for the regional colleges. On the other hand, their own comrades on the kibbutz no longer saw the regional institutions as the way to increase educational opportunities for their young people. Eventually, the regional colleges might have become institutionalized, as community colleges have in the United States, with a myth of legitimacy based on responsiveness to local needs and equal opportunity (Carnegie Commission, 1970). In the Israeli context, which had no such conception of postsecondary education, such a myth would have taken a long time to become rooted.

Operationally, the situation was otherwise. From the beginning, the colleges offered courses that were very responsive to the interests of the local populations. They provided instruction to people who could not have studied elsewhere, such as adults of Asian-African backgrounds. People who would not ordinarily spend much time together - a Moroccan manual laborer, a Russianborn kibbutz member, Israeli Arabs - sat in the same classroom. Most of these people were taking nonacademic cultural and technical courses; at most, onefifth of the students were enrolled in academic courses for credit.

Funding for the regional colleges was relatively assured, with about onethird coming from regional councils, about one-half from the Ministry of Education, and the remainder from other ministries such as Labor for special programs and from student fees. Day-to-day operations could proceed fairly smoothly. A rich and varied menu of courses was assembled several times a year, teachers from around the country were lined up, word was gotten out to the towns and villages in the region, students were transported to classes after work, registration and advising were accomplished, and even amenities like coffee and a social room were laid on.

But life at the colleges at this level was divorced from what went on at the institutional level. Just as the kibbutzim withdrew from the regional colleges, the Ministry of Education attempted to exert some control over the various new programs in postsecondary education started in the 1960s. For the first time in the history of the regional colleges, the universities and the Council for Higher Education were brought onto the scene officially. These developments had fateful consequences for the regional colleges, which found themselves intertwined with five separate major organizations on a regular basis, each of them highly institutionalized in its own right but without a strong basis for working together: the Ministry of Education, regional authorities, the kibbutzim, the universities, and the Council for Higher Education. 


\section{The Regional Colleges Confront the Institutional Context}

With the appointment of the Lifson Committee by the Ministry of Education, the regional colleges became part of an emerging postsecondary system in Israel. This committee, chaired by a respected professor of physics from the Weizmann Institute, was charged with the task of surveying postsecondary education in Israel for the first time and of proposing principles for its development in the future. Composed of eight members besides Lifson, all of them eminent professors from Hebrew University and Tel Aviv University, the committee reported to the Council for Higher Education in 1971 and recommended that the future development of postsecondary education be based on the following principles: (1) expanding, deepening, and partly academicizing existing postsecondary institutions, (2) increasing the pool of postsecondary education students, (3) dispersing the learning population, (4) introducing new technologies in education, (5) developing a national policy for the implementation of these principles.

The committee suggested some devices to carry out the policy. A network of regional colleges, with academic courses to be offered toward the BA, should be recognized by the existing universities. Adult education courses without degree implications would be offered alongside the proposed academic courses. The Lifson Committee also proposed that single-focus institutions, such as teachers' training colleges and technological schools, be expanded into comprehensive institutions. Accreditation for such colleges was recommended by the committee, although it did not specify how this was to be accomplished. The committee also recommended the establishment of an experimental open university modelled on that of Great Britain. Finally, the Lifson Committee recommended that a central body coordinate all of the regional colleges.

The Lifson Committee represented the first legitimation from the academic establishment of an egalitarian conception of postsecondary education in Israel. In effect, it laid out a blueprint for the development of a system of postsecondary education that would exist alongside but not directly challenge the university system. Heads of the regional colleges, basking in the glow of such unaccustomed attention, circulated a document to influential people on the postsecondary education scene which asserted that the Lifson Committee's idea of a network of regional colleges was compatible with their aims. They pointed out that there could be two models of university sponsorship. The first, an extension model, would give student status in the universities to students enrolled in the regional colleges. The second, a transfer model, would provide academic courses in the regional colleges, which universities would recognize as worthy of academic credit. They suggested that there be even further development of the regional colleges beyond what the committee had recommended, with the possibility that the regional colleges would award academic degrees on their own. 
These proposals from the college heads proved to be too optimistic, for the ensuing years would bring the various organizations in the institutional context of postsecondary education into direct conflict about what the colleges should be. These conflicts centered almost exclusively on whether and how they should provide academic credit for their courses.

\section{Attempts to Institutionalize Postsecondary Education in Israel and Implications for the Regional Colleges}

1972 was a crucial year in the development of postsecondary policy in Israel. The rate of growth in enrollments was just beginning to decline. In that year, the 1958 law establishing the Council for Higher Education was amended to empower the Council, and only the Council, with licensing authority for institutions of postsecondary education. Until then, as we have noted, such an authority did not exist in Israel. It was under those looser conditions that the regional colleges were established and called colleges. The 1972 law said, in effect, that only institutions licensed by the Council for Higher Education could award credit toward the BA. The question was whether the regional colleges would be licensed. To address this question, the Central Committee recommended by the Lifson Committee the year before was appointed to look into postsecondary institutions, including teachers' training colleges, technical colleges, and regional colleges.

Yet another committee, the Porat Committee, was appointed by the Council for Higher Education to examine the same question at the same time. Headed by a high official of the Ministry of Education, this committee concluded that it could not deal with the complicated questions raised by the variety of postsecondary institutions it was asked to license, and it asked to be disbanded. The Central Committee was given the task, relinquished by the Porat Committee, of deciding which of the colleges should be licensed. With thirty members from the universities, the Ministry of Education, the Ministry of Labor, industry, the kibbutz movement, and the labor movement the Central Committee could not agree on the criteria which should govern the licensing of postsecondary institutions. After a year of arguing, the committee was disbanded.

At this point, the Council for Higher Education summarized its own internal discussions of the colleges in a major document issued in 1975. This document reflects an emerging consensus on the Council about postsecondary education that can be traced to the almost continuous attention that had been given to the regional colleges in the previous five years. It recommended that no new university be established in Israel and that there be a distinction made between a "college" and an "authorized college". Only authorized colleges could award a BA or academic credits. Colleges could be authorized if they provided 
special training unavailable at the universities, as for teachers, or if they served populations that did not have access to other postsecondary institutions. Graduates of authorized colleges could continue studying for advanced degrees but the colleges themselves could not give advanced degrees. New courses would have to be approved by the Council for Higher Education, which additionally urged that the colleges have their own full-time teaching staffs rather than relying on university faculty "moonlighting" on top of their regular loads.

It is clear that the Council was searching for a justification for licencing at least some of the colleges that already existed, while preventing the proliferation of new ones [7]. Despite the fact that it represented the interests of the universities more than any other organization in postsecondary education, the Council did not entirely please the universities with this document. The universities were far from enthusiastic about the authorization of a new brand of "inferior" academic institution. It made little sense, they argued, to freeze the number of universities while at the same time accrediting colleges to offer BA degrees at lower standards.

Yet another committee was appointed by the Council for Higher Education, this time in 1977, again to examine the question of accrediting the colleges. The Poliakov Committee, with fifteen members drawn from the universities, the Council for Higher Education, the national labor federation, and the national student union, agreed that the regional colleges could not be independent institutions of higher education as they existed but they differed on how to change the situation. The majority of the members - twelve out of fifteen recommended that the colleges take the necessary steps to become authorized colleges with their own faculty and curriculum. Three of the fifteen committee members recommended that the regional colleges instead institutionalize their university sponsorship under an extension model.

The recommendation of the majority on the Poliakov Committee was never implemented, partly because of pressure from the universities and partly because the leaders of the regional colleges themselves began to doubt their ability to mobilize the resources to establish the colleges as independent institutions. In a shift from their goal of independent status during the euphoric early 1970s, the regional colleges were now in favor of an extension model. In effect, they opted to institutionalize their relationships with the universities.

Why did they take this position, particularly in view of the fact that their budgets were virtually guaranteed? We would argue, following the institutional perspective, that the issue of academic status for the regional colleges was a symbolic issue. Establishing an identity and securing legitimacy were the key problems throughout the existence of the regional colleges and particularly after kibbutz support weakened. Since there was no official national policy to equalize postsecondary education - despite the advocacy of the Ministry of Education and regional authorities - the regional colleges could not establish their legiti- 
macy by invoking that conception. Who provided legitimacy in Israeli higher education? Clearly it was not the Ministry of Education and regional authorities, but the universities and the Council for Higher Education.

\section{Partial Institutionalization, Partial Legitimacy}

Why did arguments about the regional colleges throughout this period focus on academic credit and the BA? Certainly not because of the numbers of students involved: on the average across all of the regional colleges, at most $20 \%$ of the enrolled students took courses for academic credit. Most of these older students were already established in their work, so academic credit was not linked to certification for jobs.

It is precisely because the problems facing the regional colleges had more to do with legitimacy than with their daily operations or enrollment pattern that academic credit became a critical issue. The universities in Israel, like universities everywhere, justify themselves and judge others in terms of standards which can only be judged by academics. The currency of academic standards is credits and grades. Control over that currency is a serious matter for academics. It was much less important to the universities and the Council for Higher Education what standards were being invoked in continuing education courses, for these did not involve granting credits. But if the regional colleges wished to gain legitimacy as academically respectable institutions in Israeli terms, they would have to offer bona fides for the academic credits they granted. When it became clear that accreditation as independent colleges would be a struggle at best, the heads of the regional colleges tried to work out a modus vivendi with the universities that permitted them to offer academic credit as extensions of the universities.

The colleges also came under the scrutiny of those on the other side of the argument, the Ministry of Education and the regional authorities. One indication of this concern was the appointment in 1978 of a special staff member in the Ministry of Education to deal with the regional colleges. In 1978, the Council for Higher Education, on its side, appointed yet another committee to look into the issue of the regional colleges. The Meyer Committee, chaired by another respected university professor, included the usual group of university people but this time it also had one of the most influential directors representing the regional colleges. The committee asserted unequivocally that the regional colleges were "conservative" institutions with no ambition to become independent. They were not, therefore, a threat to the universities. Given this fact, the academic curriculum should be modified to reflect the needs of the regions rather than remaining carbon copies of university courses, as they had been all along. It recommended that academic credit granted through extension courses taught in the regional colleges be made more systematic. It urged that the universities recognize each 
other's credits when they were given in courses taught within the regional colleges. The committee approved the principle, in operation for a long time, that students in the regional colleges be permitted to earn up to two of the three years required for the BA in Israeli universities. The committee also recommended that courses offered through the regional colleges be concentrated in a limited number of areas to provide more coherence and that a permanent Meyer Committee approve new courses. Finally, it urged that a central academic committee for all of the regional colleges be established.

The Meyer Committee became a permanent committee of the Council for Higher Education. It was divided into two subcommittees, one to deal with academic courses and budgets and the other with nonacademic courses. These committees were carefully designed to balance the interests of all of the organizations involved with the regional colleges. The nonacademic courses became part of a formal structure and the regional colleges had their own representatives on the key committees. At this writing, these committees provide a formal step in the institutionalization of the regional colleges.

But the regional colleges have lost ground overall in the institutionalization of postsecondary education overall in Israel. In 1977, the legal basis for the relationship between the Council for Higher Education and the regional colleges was abolished. An amendment that year to the Council for Higher Education law dropped the term "college" from its jurisdiction. No longer would "college" be a protected term carrying the assumption of academic status, for it would not be accredited by the body authorized to do so. The regional colleges were not accredited on their own. Their connection to the Council and to the world of academic credits and degrees came through their extension arrangements with sponsoring universities.

The regional colleges have not yet found an identity which might balance their two sides. In the context of Israel, perhaps this is unnecessary or even undesirable. Indeed, the academic courses can be seen as providing a "cover" for the real work of these colleges: the provision of new opportunities for the under-prepared adults located in areas poorly served by universities. That a small number of the adults in these areas are actually enrolled in academic courses is institutionally relevant. They are needed to provide academic legitimacy to the colleges and their leaders.

\section{Summary: The Institutional Context as a Focus}

The process which characterized the institutionalization of the regional colleges cannot be separated from the institutionalization of postsecondary education as a whole in Israel, and vice versa. The effort in the 1970s to define a rational basis for the standardization and control of postsecondary education 
after a decade of unplanned expansion is not unique to Israel or even to the educational sector. This is precisely what an institutional framework would predict (Meyer and Rowan, 1977). More unique is the particular set of organizations which entered the new postsecondary institutional context. In the Israeli case, these organizations had inconsistent and conflicting conceptions of postsecondary education in general and of the regional colleges in particular. Because of the historical circumstances in which the postsecondary sector grew up in Israel, the conceptions in conflict centered around egalitarianism and meritocracy, themselves reflections of deeper social cleavages in Israeli society, in particular between the "Oriental" and the Western population. In general, the Ministry of Education and regional authorities, in speaking for egalitarian access, represented the interests of the Oriental population, while the universities and the Council for Higher Education stood for meritocratic access. The regional colleges were caught in the struggle between these two sides and found themselves on constantly shifting ground as they struggled to find identity and a basis for legitimacy.

Under these conditions, some of the responses described in the beginning of this article when organizations go through an institutionalizing process under conditions of conflict were manifested: (1) the incorporation of practices and procedures from the institutionalized sector, many of which may conflict with one another; (2) struggles over identity reflected in unclear boundaries; (3) increasing scrutiny; (4) loose coupling between the institutional and the operational realms.

Let us trace the role of the major organizations in the emerging institutional context which surrounded the regional colleges. In the initial period of their formation, the regional colleges existed in a kind of "no-man's land". They would undoubtedly not have come into being without the initiative taken by the kibbutzim, which not only supplied know-how, experienced staff and students but legitimacy as well. But just as the kibbutzim withdrew from actively supporting the regional colleges, organizations on the national scene were beginning to define postsecondary education as a new concern. The development of the regional colleges from that point was intertwined with this concern.

In the meantime, the regional colleges received support from regional authorities, support that has remained stable throughout their history. Interested in providing more educational services to their populations and in bridging the gap between the center and the periphery in Israeli society, the regional authorities supported the colleges by allocating money and sending students to the colleges. They did not enter actively into disputes about the basis for the colleges' legitimacy.

The role of national organizations was more variable. The Ministry of Education has faithfully supplied the colleges with about half of their budgets. It has also viewed the colleges in somewhat different ways according to shifts in its 
own educational policies. At first, it saw the colleges as serving local needs in a general way. Later, it thought of the regional colleges as sites for bringing poorly-educated students and better-educated students under the same roof. On this conception of equalizing access to postsecondary education, the presence of students from the kibbutzim was crucial. This meant that the Ministry of Education would be in favor of granting academic credit for some courses taught in the regional colleges to attract better-prepared students and to signal their academic respectability. While the Ministry of Education wanted to see the regional colleges authorized to operate as independent colleges, they did not press this issue in the face of opposition from the universities and a mbivalence, at best, on the part of the Council for Higher Education.

The universities, whose stand on the regional colleges became more crystallized over the years, were ambivalent enough not to constitute a clear opposition. When Israeli higher education was expanding, the universities could afford to support the regional colleges through the provision of teachers, who benefited from moonlighting arrangements. Some of the universities, especially the newer, more Americanized ones, viewed their involvement with the regional colleges as a way of differentiating themselves from the older universities through the provision of services to under-served but academically qualified populations in the hinterland. But as student enrollments in the universities began to stabilize in the mid-1970s and as budgetary constraints began to be felt, the universities viewed the colleges as potential competitors. New organizations which compete with more established organizations in the same domain have the most difficult time gaining legitimacy, and the regional colleges were no match for the universities. After a short-lived attempt to gain independence as academic institutions, the regional colleges opted for a safer role as university clients. As patrons, the universities could then moderate their opposition to the upstart colleges.

The Council for Higher Education was closely associated with the universities. A relatively new body when the regional colleges were founded, the Council in its early years took a laissez faire attitude toward the development of new academic institutions in Israel. Then, in 1972 when it became apparent that expansion had gone too far, the Council for Higher Education began to tighten up. One of the manifestations of this change was an amendment to the Council for Higher Education Law empowering the Council to license academic institutions.

In the Council's efforts to control postsecondary education, the regional colleges were vulnerable partly because they overlapped with the universities as comprehensive institutions and partly because they held promise as competing centers for adult education. We have documented the ambiguous recommendations made by the numerous committees which met during the 1970 s as they foundered on both the challenges and promises of the regional colleges. The number of committees appointed to scrutinize the regional colleges is a leading 
indication of their significance in the emerging postsecondary institutional context. This reflects the basic struggle over finding terms in which the regional colleges could be defined as legitimate educational organizations with a unique identity. The most serious critics of the regional colleges never publicly suggested that they be closed. They served underprivileged populations high in the government's priorities. Such attention could not be completely ignored, even by meritocrats in the universities and on the Council.

The legitimation of academic institutions rests with the granting of academic credit. Although no one organization in the institutional network had dominance overall, on this matter all of them deferred to the universities. When they did so, the regional colleges acquired a form of legitimation conditional on the willingness of the universities to provide courses to the colleges which carry academic credit: a borrowed legitimacy. As long as the universities continued to provide this halo, the regional colleges were free to carry on their business pretty much as they always had.

\section{Notes}

1 The authors gratefully acknowledge the help of Micha Tal and Shmuel Daniv in providing us with documents and statistics. Comments on drafts on the article from Shmuel Bendor were extremely helpful, as were those of John Meyer, Mayer Zald, Rosabeth Kanter, Seymour Spilerman, and Murray Edelman. Support for the project came from a University of Michigan Rackham Graduate School faculty research grant and the Szold Institute for Behavioral Science. Kay Maves of the Center for the Study of Higher Education, University of Michigan, provided research assistance. An earlier version of this article was read at the Pinhas Sapir Conference on Development, Social Policy Evaluation: Health, Education and Welfare, Tel Aviv University, 1980.

2 The research for this article was conducted in Israel in the period 1977-1980 by the two authors. Interviews were conducted with directors and staff at five regional colleges, officials in the Ministry of Education involved in postsecondary education, the founding secretary of the Council for Higher Education, and the chairmen of three of the four committees mentioned in the text. Documents analyzed for this article include the archives of the regional colleges, the reports of the four committees, the report of the Central Committee of the colleges, and all minutes of the Council for Higher Education on the issue of the regional colleges from 1969 to 1978.

3 Teacher's training colleges enroll the largest number of students among the nonuniversity colleges (11,732 in 1977-1978), followed by colleges for practical engineers and technicians $(7,133)$ and the regional colleges $(5,776)$.

4 The role of private local initiative in founding the regional colleges resembles the U.S. pattern more than the Western European one (Carnegie Commission, 1970).

5 This mixing is, again, more like community colleges in the U.S. than those in other countries, whose programs tend to be more narrowly defined (Carnegie Commission, 1970).

6 The "mechina," a preacademic program at the universities, gave those without the matriculation certificate the opportunity to enter a university after successful completion. Younger people 
take this option. The regional colleges are another channel, especially for older people with families and jobs who live far from a university.

7 Just as these deliberations were going on, a new regional college was opened in 1975 in an educational center near Beersheba with academic courses taught by faculty from Ben-Gurion University, the newest university in Israel. Postsecondary education in Israel was not institutionalized yet!

\section{References}

Aldrich, H. E. (1979). Organizations and Environments. Englewood Cliffs, N.J.: Prentice-Hall.

Aldrich, H. E. and Pfeffer, J. (1976). "Environments of organizations," Annual Review of Sociology 2: 79-105.

Benson, J. K. (1975). "The interorganizational network as a political economy," Administrative Science Quarterly 20: 229-249.

Blau, P. (1964). Exchange and Power in Social Life. Chicago: University of Chicago Press.

Bowles, S. and Gintis, H. (1976). Schooling in Capitalist America. New York: Basic Books.

Carnegie Commission on Higher Education (1970). The Open-Door Colleges: Policies for Community Colleges. New York: McGraw-Hill.

Cohen, M. D. and March, H. (1974). Leadership and Ambiguity. New York: McGraw-Hill.

Collins, R. (1979). The Credential Society: An Historical Sociology of Education and Stratification. New York: Academic Press.

Dowling, J. and Pfeffer, J. (1975). "Organizational legitimacy: social values and organizational behavior," Pacific Sociological Review' 18: 122-136.

Gamson, Z. F. and Palgi, M. (1982). "The 'over-educated' kibbutz: shifting relations between social reproduction and individual development on the kibbutz," Interchange 13: 55-67.

Hall, R. H., Clark, J. P., Giordano, P. C., Johnson, P. V. and van Rockwell, M. (1977). "Patterns of interorganizational relationships," Administrative Science Quarterly 22: 457-474.

Horowitz, T. (1980). "Integration and the social gap," The Jerusalem Quarterly' 15: 133-144.

Israel Bureau of Statistics (1979). Education.

Jacobs, D. (1974). "Dependency and vulnerability: an exchange approach to the control of organizations," Administrative Science Quarterly 19: 45-59.

Larson, M. S. (1977). The Rise of Professionalism: A Sociological Analysis. Berkeley, California: University of California Press.

Levin, H. (1980). "Workplace democracy and educational planning," in Education, Work and Employment. Paris: Unesco, International Institute for Educational Planning.

Levine, S. and White, P. E. (1961). "Exchange as a conceptual framework for the study of inter-organizational relationships," Administrative Science Quarterly' 5: 583-601.

Meyer, J. W. (1970). "The charter: conditions of diffuse socialization in schools," in W. R. Scott (ed.), Social Processes and Social Structures. New York: Holt, Rinehart and Winston.

Meyer, J. and Rowan, B. (1977). "Institutionalized organizations: formal structure as myth and ceremony," American Journal of Sociology 83: 340-363.

Meyer, M. W. and Associates (eds.) (1978). Environments and Organizations. San Francisco: Jossey-Bass.

Meyer, N. and Brown, M. C. (1978). "The process of bureaucratization," in M. W. Meyer and Associates (eds.). Environments and Organizations. San Francisco: Jossey Bass.

Pfeffer, J. and Salancik, G. R. (1978). The External Control of Organizations: A Resource Dependence Perspective. New York: Harper and Row. 
Rosner, M. (1982). The Second Generation: The Kibbutz Between Continuity and Change. Darby, Pennsylvania: Norwood Press.

Salancik, G. R. and Pfeffer, J. (1974). "Bases and use of power in organizational decision making: the case of a university," Administrative Science Quarterly 19: 453-473.

Smilansky, M. (1973). "The challenge of disadvantaged children in the education system," in H. Ormian (ed.), Education in Israel. Jerusalem: Keter (Hebrew).

Talbert, J. E. (1979). "Accountability and School Management: An Exchange-Theory Model." Stanford, California: Center for Research on Education at Stanford, Stanford University.

Weick, K. E. (1976). "Educational organizations as loosely coupled systems," Administrative Science Quarterly 21: 1-19.

Wiley, M. G. and Zald, M. N. (1968). "The growth and transformation of educational accrediting agencies: an exploratory study in social control of institutions," Sociology of Education 41: 36-56.

Yuchtman, E. and Seashore, S. (1967). "A system resource approach to organizational effectiveness," American Sociological Review 32: 891-902.

Zald, M. N. (1970). "Political economy: a framework for analysis," in M. N. Zald (ed.), Power in Organizations. Nashville, Tennessee: Vanderbilt University Press. 